\title{
Comparative performance of Islamic and conventional insurance companies in Pakistan
}

\author{
Hafiza Tahira ${ }^{1}$, ZeeshanArshad ${ }^{2}$ \\ MS Scholar, Department of banking and finance, University of Gujrat, Pakistan \\ Department of banking and finance, Faculty school of business, University of Gujrat, Pakistan
}

\begin{abstract}
Takaful is Islamic insurance which is the most appropriate substitute of conventional insurance for individuals and financial institutions. Takaful is being used by several banks in the world to assist their customers who are paying attention to have the Islamic features of insurance. There are several studies on the comparative performance of the Islamic and conventional insurance companies in Pakistan. Most of the conducted research focused on the demand determinants of the insurance sector. This study is an attempt to provide a fair picture of the Islamic and conventional insurance companies. The purpose of this study is to investigate the factors like profitability, liquidity, risk and solvency and capital adequacy. The data from 4 takaful and 15 conventional insurance companies have been taken from the year 2008 to 2011 as takaful insurance industry have been started in Pakistan in 2006. Descriptive statistics andAnova analysis are applied on the data to find out the performance of insurance companies. The overall result shows that Islamic insurance companies perform well.
\end{abstract}

Key words: Takaful insurance, conventional insurance, financial ratios, Anova, Pakistan.

\section{Introduction}

In this world, everyone is exposed to the possibility of risk and disasters such as death, losses and damages through fire, accident, and business etc. we have to accept any catastrophe that happens as the will of God but they are also enforced to take positive steps to reduce unfortunate events.Everyone must find ways and means to keep away from such troubles and one should try to minimize his financial losses. One possible way to overcome the catastrophe is to buy an insurance cover. Insurance provides the means for people to transfer the burden of uncertaintyto the insurer, for an agreed financial consideration called the premium. In exchange, the insurer promises to provide financial compensation to the insured should a specified loss occur. It is also called risk transfer mechanism in which one can exchange his uncertainty of financial loss for the certainty of the premium. Individuals, business enterprises make innovations and inventions which takes great risk. Greater responsibility falls on the shoulders of innovators and inventors. A small mistake may cause numerous side effects, disability or cause of death. These types of risk highlight the importance of insurance. In peace the insurance provides protection to trade and industry, which ultimately contributes towards human progress. Thus insurance is the most lending force contributing towards economic, social and technological progress of man. Without insurance cover all industrial, economic and social activity of the world will come to a grinding halt.

\subsection{Takaful Insurance}

In Islam the Arabic term of takaful is denote in place of insurance that means assuring each other. The root of the word takaful is kafala which means to look after each other or mutual guarantee or protection .Takaful is based on the principle that the pool of donations is created and is used to support each other. It is a mutual agreement by a large no of donors to protect those who are in great risk. Fatwa was given in the National Council for Muslim Religious Affairs in Malaysia that the amount is distributed in accordance with the principles of Wasiah if the assured dies. The principles of Takafulare Ta'awun (mutual assistance), Tabarru (Gift, Give away, donations) and Aaqilah. Aaqilah means that in case of any natural disaster, every person used to contribute something until the loss was indemnified. Islam accepted this principle of mutual compensation and joint liability. Participants in takaful insurance mutually agree to give certain proportion of their contribution to the Shariah funds for the financial assistance of the group members suffering from a loss. The main purpose of Takaful under the Islamic system is to bring equity to all parties involved, and the objective of the contract is to help the policyholders through bad times, creating brotherhood and solidarity. Profit earnings are not the main goal, while sharing any profit generated is acceptable.Takaful also applies the indemnification principle and compensate the loss of Takaful client. Takaful is only related with pure risk but not with speculative risk. Pure risk means that there are equal chances of occurring and none occurring of loss. On the other hand speculative risk means that there may be loss, profit or no loss. The funds of takaful are managed by operators but ownership is remained in the hands of participants. They have a complete right of contribution and benefits. It performs trustee and operator functions. Shariah Council determines where to invest funds so that 
interest factor must not $\mathrm{b}$ involved in business investment. All the investment rules are made on the basis of Holy Quran and Sunnah of Prophet (PBU).Dawood Taylor 2008 quoted the Hadees of prophet Muhammad (PBUH), which he told to a Bedouin Arab, who left his camel untied to the will of Allah, "tie the camel and then leave it to the will of Allah". Thus the saying suggests the importance given by Prophet Muhammad (PBUH) to the concept of protection.Muslim jurists concluded that:

- Insurance should be based on the principles of mutuality and cooperation.

- Insurance products should be founded on the basis of Tabarru, an Arabic noun meaning' donation, gift, contribution'.

- The insurance company must conduct all its affairs in line with the Shariah.

- The participants mutually contribute to the same fund for the purpose of mutualindemnity in case of risk and harm.

\subsection{Takaful Operational Models:}

There are three takaful operational models that are mudharbah model, Wakalah model and WakalahWaqf model.Mudaraba model describes that all policy holders must agree to share profits or losses from undertaking. Under this model, the operators do not have to pay a commission but will receive a salary which will be paid from share of profits made by the company. The sharing of profits and losses are determined in advance according to the agreement. This sharing ratio is approved by the Shariah committee board on advance basis. Normally total expenses are charged to shareholders. Wakalah model describes that the surplus of policyholders funds and management fee or expenses go to the policyholders. The participant pays the Wakalah fee from contributions. This contribution covers the total operator expenses and operator salaries of the business. This Wakalah fee is determined by the Shariah advisory board of the company one year advance basis. To give incentive to operator for good governance, management fee is paid as per the level of performance. Wakalah Waqf model or Wakalah fund is created as separate legal entity with the contribution of the participant's amount and the amount deposited to this fund is considered as a "tabarru"donation (Husain and pasha 2011). The objective of this fund is to provide relief to participants against defined losses according to the terms and condition of the Waqffund.

\subsection{Conventional Insurance:}

Under conventional insurance the main perspective of insurance is to minimize the risk. The funds pooled from large no of policy holders are reinvested in interest bearing instruments. Conventional insurance is forbidden in Islam because it contains the element of Riba, Maisir and Gharar. These three elements are the exploitive tools for the conventional insurance.Ribameans interest or any increase in principal amount that is due within specified period. In conventional insurance contracts, funds are mostly invested in interest based opportunity where return is preset and definite no matter how much investor earns profit from the investment. According to the translation of the verse of the Quran S-ii, 274 say "God hath permitted trade and forbidden usury". The Quran has clearly forbidden all business transactions that involve riba and cause injustice in any form to any of the parties.Maisir means speculation or gambling In other words insured pays a premium in the expectation of compensation against claim. If the anticipated loss does not occur, the insured loses the amount paid as premium. If the loss does occur, the insurer loses a far larger amount than collected as premium and the insured gains by the same. "Satan's plan is (but) to excite enmity and hatred between you, with intoxicants and gambling, and hinder you from the remembrance of Allah, and from prayer: will ye not then abstain?" Al-Quran (3:91). So Quran has warned against all such transactions which involve gambling. Ghararis Arabic term which meansuncertainty of terms resulting in deception or lack of clear conditions and terms. Quran has forbidden such transactions that involve gharar and cheat to any party by hiding some facts or providing inaccurate information. According to the Quran (83:1-3) "Woe to those who deal in fraud, who when they take their measure from others take it fully, and when they measure or weigh for them give less than what is due." The Prophet (SAW) said, "When you enter into a transaction, there should be no attempt to deceive. "uncertainty in transactions may lead to deception, fraud or undue advantage to one party due to lack of disclosure and transparency about the terms of contract. By watching the incidents we can say that any business transaction in which either party has an intention to deceive is clearly haram by Quran and Sunnah.

\subsection{Difference between Islamic and Conventional Insurance Companies:}

There are significance differences between Islamic and conventional insurance companies that are

- Joint Guarantee/Ta'awun

- $\quad$ Social Solidarity/ Shared Responsibility

- Concept of Aaqilah

- Risk Distribution

Joint Guarantee/Ta'awun: 
In takaful insurance Islamic financial protection are lies under the head of joint guarantee scheme in providing possible indemnity. On the other hand conventional insurance is based on compensation of loss that is paid by insured in exchange of premium. The basic principle of Islamic insurance system is Ta'awun and tabarru. Participants are mutually agreed to help and guarantee each other for the sake of mutual cooperation. Profit earning is not a main goal but to share this profit among the suffered participants is the goal but on the other hand the basic principle is to earn profit.

\section{Social Solidarity/ Shared Responsibility:}

Takaful is based on the idea of social solidarity, mutual cooperation and joint indemnification of losses of the members. There is an agreement among the members that if any one of them suffered from a loss they will contribute collectively to contribute the fund. On the other hand there is not any religious boundary, there purpose is not to averse the risk from suffering the people.

\section{Concept of Aaqilah:}

According to Muslim jurist acknowledge that Aaqilah is an arrangement of mutual help in some tribes at the time of Holy Prophet (PBUH). In case of any catastrophe every person used to contribute something until the loss is indemnified. Islam accepted this principle of mutual help and joint liability.

\section{Risk Distribution:}

In Takaful insurance system risk is not exchanged by a way of contribution payment made to operator. In this operator is not selling and participants is not buying any risk coverage. Operator is not undertaking risk because he is working under the role of fund manager on behalf of the participants. However risk is distributed among the participants as per the jointly assume the risk. On the other hand conventional insurance system the first party agrees to undertake the risk of other party in exchange of premium and the other party promises to pay fixed sum of money to the first party on the happening of uncertain event with in a specific duration (Spence and Zeckhauser,1971).

\subsection{Significance/Rationale of the Study:}

The insurance company's contribution in Pakistan is not up to the mark as like in Malaysia, Saudi Arabia and UAE etc. The reason behind is the lack of awareness to the general public and the scarcity of Shariah Scholars with appropriate experience. This paper helps to the create awareness of the benefits of Islamic insurance sector in Pakistan and provide insight information to the shareholders, customers, management and investor. This paper helps to arouse the need of Shariah scholars with their relative experience.

\subsection{Contribution to existing literature:}

In Pakistan, nobody has done the ratio analysis on insurance sector, that's whyl'm going to contribute in this study the ratio analysis and Anova as this is not used in any of the research paper. Financial ratios are an important tool of economic decision-making for all businesses. The ratio analysis involves method of calculating and interpreting financial ratios to assess the performance. These ratios are the sign of financial performance of insurance companies. With the ratio analysis owners of the insurance companies can easily forecast the trends of the future.This paper covers the aspects of Islamic and conventional insurance that indicate the financial health of conventional as well as Islamic insurance and provide true and fair picture of insurance company's financial position to the management, shareholders, investors and general public.

\subsection{Research Objectives:}

There are two main research objectives one is primary objective and the second one is secondary objective.

1.7.1Primaryobjective: Primary objective is to compare the performance of Islamic and conventional insurance companies in Pakistan.

\subsubsection{Secondary objectives:}

- Provide the awareness to general public about the benefits of Islamic insurance companies.

Mechanism of general takaful in Pakistan.

Factors those make insurance prohibited in Islamic context.

The focus on the study is to find those factors that can be the reasons of loss.

\subsection{Plan of Study:}

Section 1 provides the objectives of study and introduces the researchPurpose. Section 2 contains the literature review; section 3 explains the research methodology used in the analysis of this paper; section 4 consists of 
analysis of data and empirical results. Section 5 endorses the findings; study is concluded in section 6 and section 7 provides the suggestions upon the findings.

1.9 Hypothesis:

$\mathbf{H}_{1}$ : Islamic insurance companies are more profitable than Conventional insurance companies.

$\mathbf{H}_{2:}$ Islamic insurance company's liquidity is higher than conventional insurance.

$\mathbf{H}_{3:}$ Islamic insurance companies are less risky than Conventional insurance.

$\mathbf{H}_{4}$ Islamic insurance are well capitalized than Conventional insurance companies.

\section{Literature Review}

Matsawali et al (2012) describes in their research paper that Takaful insurance system based on Islamic principles that are mutual assistance and voluntary contribution. The research objective was to know the public preference and understanding between the conventional and Islamic insurance in Brunei. For this purpose a survey was conducted in which questionnaire based on 3 sections, demographic section, respondents preferences between takaful and conventional insurance products section and the last one section about the respondents understanding about the takaful. Primary data were taken from the survey and secondary data were from journals, published articles, and takaful companies. Results concluded that people preferred to takaful because to Islamic insurance but they have limited awareness about the takaful. (Matsawali et al,2012).

Muhammad Ayub describes in his literature about the takaful insurance and presents the takaful as a substitutive of the conventional insurance system. He defines the takaful as an insurance system in which people acts as a group of people who agrees to jointly cover the loss that may inflict upon any of them, out of the fund they denote collectively. According to him Takafulcompanies undertake only Shariah compliant business and profits of takaful insurance companies are distributed according to pre agree ratio. Researcher has also defined the operating models of takaful that are Mudharbah model, Wakalah model and Wakalah Waqf model. (Muhammad Ayub).

Asif Ahmed Qureshi(2011) discussed the Shariah compliant issues that is currently faced by the takaful insurance. His study shows those elements that are currently found in an Islamic insurance system of the conventional insurance system whether by compulsion or by the doctrine of the necessity. One of them element is management. Takaful insurance offered the portfolio backed by the Shariah board but the management of this portfolio is an external investment manager, for the purpose of success managers move their responsibilities and not works according to Shariah board. So here is the element which shows that there is need to be check and balance on internal management system of Takaful insurance companies. (Asif Ahmed Qureshi, 2011)

Husain and Pasha (2011) said that Islamic insurance consisted on the concept of mutual help and association where as conventional insurance business based on uncertainty that forbidden in Islam. Differences has found of takaful and conventional insurance on the basis of models. Takaful model includes Mudaraba, Wakalah Model and Wakalah Waqf Model. This study mainly addressed the differences based on conceptual and operational framework. Conceptual framework includes Joint Guarantee/Ta'awun, Social Solidarity/ Shared Responsibility, Concept of Aaqilah and Risk Distribution where as operational framework includes Gharar, Maisir, Riba, Investment of Funds, Nature of Contract and Profit Distribution. (Husain and Pasha, 2011).

Afza and Asghar (2012) analyzed the relationship between financial reforms and efficiency in the insurance companies of Pakistan for the period of 2003 to 2007. For this purpose Data Envelopment Analysis and Regression Analysis was used to conclude the results. Study also divided in two samples that were life and non life insurers. Financial data was taken from the financial reports of 33 insurers in Pakistan. The analysis results showed that size, profitability, leverage, investments had the main drivers of efficiency. Non life insurers performed better than the life insurers in Pakistan. Claim variables were the positively related with the life and negatively related with the non life insurers. As a whole it showed that financial reforms showed better performance in the scenario of Pakistan. (Afza and Asghar, 2012).

Mehdi Sadeghi (2010) conducted a research that was based on literature survey of the evolution of Islamic insurance. He examined the literature from theoretical and practical perspective. Takaful insurance suffered the benefits of low transaction cost, high trust relationship between policy holders and operators whereas in conventional insurance the relationship between insurer and insured based on risk. (Mehdi Sadeghi, 2010).

Khan et al (2011) said in their research paper that conventional insurance system based on interest charged system where uncertainty chances are great. Islamic economic system based on interest free financial system. Khan et al conducted the comparative study on Islamic and conventional insurance according to the criteria of Islamic principles. He tried to find out whether Islamic insurance can overcome the conventional insurance system. Results concluded that Islamic insurance is more suitable and preferable in the world especially in Muslim countries. The chances of risk and uncertainty are very less in Islamic insurance system due to its 
interest free system. This Islamic system prevents the industry from the major global financial crises. (Khan et al, 2011).

Plantinga and Huijgen (1999) evaluated the investment performance of the insurance companies by developing the attribution framework model. The model was based on dual benchmark that had two objectives one was maximization of shareholder value and the second was the protection of the value of policy holders. Funeral insurance company was considering for the application of model. The benchmark distinguished the surplus driven and liability driven asset. Results conclude that investing in a company according to benchmark increase the shareholders return. (Plantinga and Huijgen, 1999).

Muhammad Anwar (1994) told that during the last decade Council of Islamic ideology Pakistan declared all the takafuls incompatible in accordance with Islam. Now it is compulsory for all takaful to implement the rules and regulations that are supervised by Shariah supervisory board. This board has the power to keep check and control system of company practices, contracts and operations. Qard al-Hassan eliminates the possibility of gambling through takaful. CIIP recommended that takaful insurance must be conducted by nonprofit organization and must also reserved some fund on side to help the deserving people that were non participants. (Muhammad Anwar, 1994).

Moghadam et al (2012) conducted research on comparing the performance of insurance companies in Iran from the month of March to December 2011. According to them measuring the performance is compulsory to gain competitive advantage in the market and to identify the top competitors for the sake of promotion in insurance companies. Descriptive statistics and ANOVA used to compare the compensation ratio and the growth rate of manufacturing premium among the insurance companies. Data collection sources were library, computer networks and data base. On the base of Anova results concluded that insurance companies had significant difference in terms of performance. (Moghadam et al, 2012).

Norma Md. Saad tried to find out the efficiency of takaful and conventional insurance in Malaysia for the period of 2007 to 2009. Twenty eight insurance companies were taken in which six were takaful of the 28 companies. Data envelopment analysis was used to measure the efficiency. in data envelopment analysis Malmquist index was used. Two inputs and outputs were considered to investigate the efficiency. Input includes commission and management expenses; output includes premium and net investment income. Results concluded that overall efficiency of takaful insurance companied below the conventional insurance companies. From the six takaful insurance companies only one company showing higher efficiency above the industrial average. (Norma Md. Saad).

Ansari and Farooq (2012) Islamic banks was the major contributor as a client in takaful business. The objective of the study was to provide the true picture to the takaful companies to recognize banks as their prospective clients. The data from 14 conventional and Islamic banks had been taken for the period of 2007 to 2009 . Leverage, working capital, expected bankruptcy cost, bank size and tax consideration was taken to check the effect on takaful contribution by bank. For this purpose researcher applied the methodology of descriptive statistics, Pearson correlation and common effect model. Results showed that working capital and bank size shows significant result on the other hand leverage, expected bankruptcy cost and tax consideration showed statistically insignificant results. (Ansari and Farooq, 2012).

Swartz and Coetzer (2010) prioritized the takaful insurance company on the conventional insurance company. According to them conventional insurance company based on interest, gambling and uncertainty while takaful insurance runs their operations on the principles of Supervisory Shariah board. They consider takaful insurance as an Islamic way of mutual assistance to deal with uncertainties of life. The objective of the research was to provide the awareness about takaful insurance that was very low, and to remove the misconception that the takaful insurance is just for Muslims. The structure of the takaful insurance was not based on profit models but it totally differs. Company is just managing the funds; there is separation between the participants and shareholders' funds. (Swartz and Coetzer, 2010).

Yon Bahiah Wan Aris researched that the first takaful company introduced in Malaysia in 1984 with the order of prime minister Tun Mahathir Muhammad. This takaful company provides services that confirms with the Islamic principles. This research paper tried to provide know how about the operations, mechanism and also on the concept of Islamic takaful insurance that how it differs with conventional insurance. To accumulate the results researcher applied regression analysis based on empirical analysis. He has taken the macro level variables of zakat, GDP, employment opportunities and inflation. Results concluded that zakat and employment opportunities showed the profitability of the general and family takaful insurance while GDP and inflation does not shows significant effectiveness of profitability. (Yon Bahiah Wan Aris).

Noreen and khan conducted research that's objective was to compare the efficiency analysis of conventional insurance and takaful insurance within Pakistan. For this purpose data had taken for the period of 2006 to 2009. Non-parametic technique was used that's based on empirical testing and Malmquist productivity index. DEA applied to estimates the technical, allocate the cost efficiencies. Empirical findings showed that conventional and takaful insurance remained cost inefficient. For takaful insurance Malmquist productivity index showed significant improvement in scale efficiency. (Noreen and khan). 
Afza and Ahmed describes that the capital structure of insurance sector has got little attention from the research point of view. Empirical study was done by the author to find out the determinants of insurance sector. Data was taken from 2001 to 2009. Data was divided in sets according to life, non life, overall insurance sector and OLS regression models to find out the relationship between dependant and independent variables that were size, profitability, Tangibility liquidity and risk. Results showed positive significant relationship of OLS models between debt ratio and size. In life and non life insurance of Pakistan liquidity and profitability has negative and insignificantly related with leverage. (Afza and Ahmed).

Marina Brogi (2003) conducted research in Italy on the topic of regulation, corporate governance and risk management in banks and insurance companies. The objective of the study was to measure the performance of the company and to investigate the role of committees in the risk acceptance. Data sample was taken from 2001 to 2003. Tobin's Q and Return on asset ratio was applied to define the models that are one-tier, vertical two-tier and horizontal two-tier. Results concluded that models showed to be effective for financial intermediaries (Marina Brogi, 2003).

Research Model:

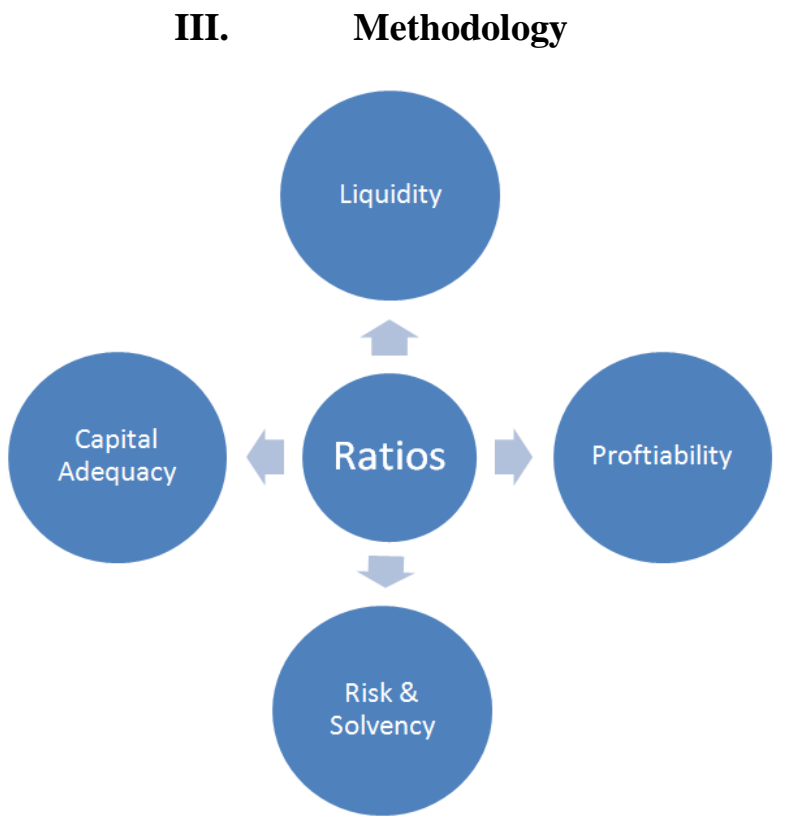

The ratio analysis involves method of calculating and interpreting financial ratios to assess the performance. These ratios are the sign of financial performance of insurance companies. Business owners can predict the future trend of their business by doing the ratio analysis. To study the comparative results of Islamic and conventional insurance companies I have done the ratio analysis for the period of 2008 to 2011 . These ratios are as follows:

\subsubsection{Profitability Ratios}

3.1.2 Liquidity Ratios

3.1.3 Risk and Solvency Ratios

3.1.4 Capital Adequacy Ratios

Table.1 Operationalization of variable:

\begin{tabular}{|l|l|l|}
\hline \multicolumn{1}{|c|}{ Ratios } & \multicolumn{1}{c|}{ Specificity } & Calculated Formulas \\
\hline ROAA & Return on average asset & Earnings after tax/Average assets \\
\hline ROAE & Return on average equity & Earnings after tax/Average equity \\
\hline CR & Current ratio & Cash and account with banks/Total deposits \\
\hline CAR & Current asset ratio & Current asset /Total asset \\
\hline LDR & Loan deposit ratio & Loans/ Deposits \\
\hline NLTAR & Net loan to total asset ratio & Net loans/Total assets \\
\hline DER & Debt equity ratio & Total Debt/Shareholder Equity \\
\hline DTAR & Debt to total asset ratio & Total Debt/ Total asset \\
\hline ELR & Equity liability ratio & Average equity/Average liabilities \\
\hline
\end{tabular}




\subsubsection{Profitability Ratios:}

Profitability ratios measure a company's ability to generate earnings in accordance to sales, assets and equity. These ratios highlights that how effectively the profitability of a company is being managed. Different profitability ratios provide different useful insights into the financial health and performance of a company.The higher profitability ratio indicates better performance of a company. We used the two main ratios that are

$\circ \quad$ Return on average assets (ROAA)

$\circ \quad$ Return on average equity (ROAE)

\subsubsection{Liquidity Ratios:}

Liquidity ratio measure the ability of a company to meet its short term debt obligations. It is a major measure of financial health. If the results of these ratios are greater than 1 it indicates that short term debts are fully covered or in other meaning is that company is in good financial health. We measure the banking liquidity position by applying these ratios that are

$\begin{array}{ll}\circ & \text { Current ratio (CR) } \\ \circ & \text { Current asset ratio (CAR) } \\ \circ & \text { Loan deposit ratio (LDR) } \\ \circ & \text { Net loan/total asset ratio (NLTA) }\end{array}$

\subsubsection{Risk and Solvency Ratios:}

Risk and solvency ratios are used to measure the degree of financial risk that a business faces, or in other words these are the tools that are used to measure the ability of a company to meet its long term financial obligations. Solvency ratio is measured by the relationship between the assets, liabilities and equity of a business at a given point in time. By using this ratio we can assess our level of debt and decide whether this level is appropriate for our company. These given ratios are used in study

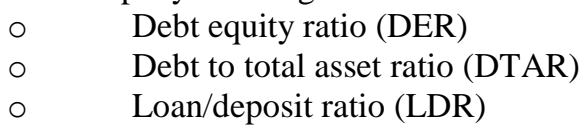

\subsubsection{Capital adequacy Ratios:}

Capital adequacy ratio is the ratio which designed to measure the capacity of a bank in the context of meeting the time liabilities and other risk (credit risk, market risk, operational risk, etc). It is a measure of bank capital position. The other name of capital adequacy ratio is capital to risk (weighted) asset ratio. I focused on the one ratio that is

$\circ \quad$ Equity/liabilities ratio

\subsection{Descriptive Statistics:}

A set of brief descriptive coefficients that precise a given data set that can either be a representation of the whole population or the sample. The measures used to describe the data set aremean, median, standard deviation that summarized and interpret some of the properties of a set of data or to the sample. As the essential job in various statistical analyses is to illustrate the location and variability of a data set, that is done by measuring skewness and kurtosis.

\subsection{Anova Analysis:}

The analysis of variance is a statistical test that is used to conclude the significance of mean differences of these ratios between and among banks. The decision criterion is $\mathrm{P}$ value. $\mathrm{P}$ value is used to indicate a probability that we calculate after a given study. If $\mathrm{P}$ value is greater than 0.05 we will accept null hypothesis and reject other hypothesis.

\subsection{Population:}

The population of the study is the Islamic insurance companies and conventional insurance companies of Pakistan.

\subsection{Data Source:}

The Audited financial statements, Income Statement and Balance Sheet of both Islamic and Conventional insurance companies for the period of 2008 to 2011 are used for ratio analysis.

\subsection{Sample:}

In KSE Index there are 29 insurance companies registered. In which 5 are Islamic insurance and 24 are conventional insurance companies. 4 Islamic company's data is available to us for ratio analysis and 15 conventional insurance companies' data available to us. 


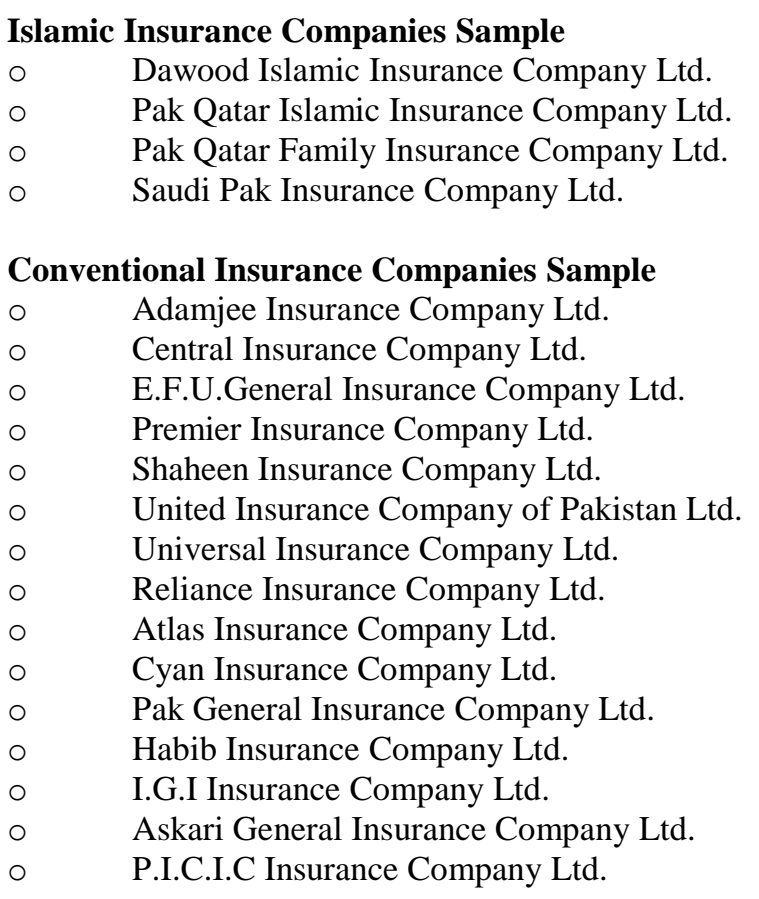

\section{Data Analysis}

Insurance sector is now getting more popular with the passage of time, as people are considering its importance in their life. From the perspective of Pakistan, the takaful insurance companies progressed a lot. The results for the insurance sector including descriptive statistics andAnova are presented and discussed below:

Table.2: Descriptive Statistics of Islamic insurance companies

\begin{tabular}{lccccc}
\hline \multicolumn{1}{c}{ Ratios } & Mean & Median & St. Deviation & Skewness & kurtosis \\
\hline Current asset ratio & 0.518301 & 0.303469 & 0.585067 & 2.7629 & \\
Current ratio & 5.903399 & 0.663123 & 10.13551 & & \\
Debt equity ratio & 0.960680 & 0.428298 & 1.392279 & 2.5867 & 9.180809 \\
Debt to total asset ratio & 0.502672 & 0.379432 & 0.482970 & 2.0866 & 7.726818 \\
Equity liability ratio & 6.887000 & 3.020560 & 9.141508 & 1.7134 & 4.751699 \\
Loan deposit ratio & 2.950178 & 1.009174 & 4.530440 & 2.1516 & 6.664289 \\
Net loan to total asset ratio & 0.117082 & 0.099115 & 0.123163 & 2.9722 & 11.31652 \\
Return on average asset & 0.241886 & -0.116948 & 2.064955 & -1.4539 & 8.812705 \\
Return on average equity & -0.336990 & -0.082893 & 2.915291 & 3.2457 & 12.53876 \\
Loan deposit ratio & 2.950178 & 1.009174 & 4.530440 & 2.1516 & 6.664289 \\
\hline \hline Total & 20.694386 & 6.712504 & 39.474023 & 21.3948 & 89.745087 \\
\hline
\end{tabular}

Table 2 shows the descriptive statistics of takaful insurance companies used in the sample of the study. Mean values providing the answers of ratios in a positive manner except return on average equity and the median values are also showing the positive results except the return on average asset and return on average equity. In most of the ratios standard deviation shows the small values except current ratio and equity liability ratio. These small standard deviations show that the values in a statistical data sample are close to the mean of the data sample averagely, wherever the current ratio and equity liability ratio shows the large values of standard deviation. It means that the values in the statistical data sample are far away from the mean an averagely. The result shows that the value of skewness for all the ratios is not within the range of $(-1:+1)$. It means that the values are departing from normality. The values of kurtosis in the table indicate that ratios are positively skewed and all are leptokurtic with higher than normal kurtosis (0-3). 
Table.3: Descriptive statistics of conventional insurance companies:

\begin{tabular}{|c|c|c|c|c|c|}
\hline Ratios & Mean & Median & St. Deviation & I Skewness & Kurtosis \\
\hline Current asset ratio & 0.4533 & 0.48372 & 0.22497 & -0.38876 & 2.59302 \\
\hline Current ratio & 8.2009 & 0.77635 & 26.3236 & 5.2618 & 33.30995 \\
\hline Debt equity ratio & 3.3047 & 2.16142 & 3.2798 & -0.41950 & 2.16373 \\
\hline Debt to total asset ratio & 0.4661 & 0.49416 & 0.22227 & 1.73829 & 4.94943 \\
\hline Equity liability ratio & 0.78019 & 0.45818 & 1.75528 & 6.9647 & 52.2247 \\
\hline Loan deposit ratio & 16.6738 & 1.65701 & 75.9187 & 7.00345 & 52.3144 \\
\hline Net loan to total asset ratio & 0.11206 & 0.10051 & 0.08053 & 1.07408 & 4.62234 \\
\hline Return on average asset & 0.01925 & 0.02142 & 0.07461 & 0.94805 & 5.01097 \\
\hline Return on average equity & 0.10553 & 0.19478 & 0.78619 & -2.92050 & 19.99364 \\
\hline Loan deposit ratio & 16.6738 & 1.65701 & 75.9187 & 7.00345 & 52.31449 \\
\hline Total & 46.78963 & 8.00456 & 184.58465 & 26.26506 & 230.30388 \\
\hline
\end{tabular}

Table 3 shows that the descriptive statistics of the conventional insurance companies used in the sample of the study. All the values of ratios in the mean and median providing the results in a positive manner, none of them are negative. Standard deviation shows the averagely small statistical data sample of the conventional insurance companies except loan deposit ratio and current ratio. The values of the skewness are not within the range of ($1:+1)$ except return on average asset that means the values are departing from normality. Current asset ratio, debt equity ratio and return on average equity ratios are showing the negative skewed results in the table. The values of kurtosis in the table indicate that ratios are positively skewed and all are leptokurtic except current asset ratio and debt equity ratio with higher than normal kurtosis (0-3).

Table.4 Anova analysis of Islamic insurance companies:

Table 4 represents the t- test as well as Anova results. T-test is used to check the significance of mean

\begin{tabular}{lccccc}
\hline \multicolumn{1}{c}{ Ratios } & Mean & $\mathbf{N}$ & St. Deviation & t-value & p-value \\
\hline Current asset ratio & 0.4533 & 60 & 0.22497 & 11.256 & 0.000 \\
Current ratio & 8.2009 & 60 & 26.3236 & 2.409 & 0.019 \\
Debt equity ratio & 3.3047 & 60 & 3.2798 & 7.805 & 0.000 \\
Debt to total asset ratio & 0.4661 & 60 & 0.22227 & 12.174 & 0.000 \\
Equity liability ratio & 0.78019 & 60 & 1.75528 & 3.284 & 0.002 \\
Loan deposit ratio & 16.6738 & 60 & 75.9187 & 1.704 & 0.094 \\
Net loan to total asset ratio & 0.11206 & 60 & 0.08053 & 7.158 & 0.000 \\
Return on average asset & 0.01925 & 60 & 0.07461 & 1.473 & 0.146 \\
Return on average equity & 0.10553 & 60 & 0.78619 & 1.226 & 0.225 \\
Loan deposit ratio & 16.6738 & 60 & 75.9187 & 1.704 & 0.094 \\
\hline \hline Total & 46.78963 & 600 & 184.58465 & 50.193 & 0.58 \\
\hline
\end{tabular}

differences between insurance companies. P value criterion of Anova shows the significance results of current asset ratio, debt to total asset ratio, equity liability ratio, net loan to total asset ratio, debt equity ratio and loan deposit ratio. It means that the profitability results are not significant wherever overall liquidity results, risk and solvency results and capital adequacy results are significant.

The liquidity position of Islamic insurance and Conventional insurance is analyzed through Current ratio, Current Asset ratio, Loan Deposit ratio and Net Loans to Total Asset ratio. CR indicates the company ability to meet its current liabilities. A higher value of CR shows that the company has more liquid assets to pay back to its depositors. CAR indicates the percentage of company liquid assets. A high CAR is sign of liquidity. LDR measure the degree of company relies on borrowed funds. The high figure of LDR shows that insurance company is more relying on borrowed funds and leads to illiquidity. Net loans to total assets ratio measures the total loans outstanding as a percentage of total assets. The higher this ratio indicates that an insurance company is loaned up and its liquidity is low (Sanaullah Ansariand Atiqa Rehman). 
Table.5 Anova analysis of conventional insurance companies

\begin{tabular}{lccccc}
\hline \multicolumn{1}{c}{ Ratios } & Mean & $\mathbf{N}$ & St. Deviation & t-value & p-value \\
\hline Current asset ratio & 0.4533 & 60 & 0.22497 & 11.256 & 0.000 \\
Current ratio & 8.2009 & 60 & 26.3236 & 2.409 & 0.019 \\
Debt equity ratio & 3.3047 & 60 & 3.2798 & 7.805 & 0.000 \\
Debt to total asset ratio & 0.4661 & 60 & 0.22227 & 12.174 & 0.000 \\
Equity liability ratio & 0.78019 & 60 & 1.75528 & 3.284 & 0.002 \\
Loan deposit ratio & 16.6738 & 60 & 75.9187 & 1.704 & 0.094 \\
Net loan to total asset ratio & 0.11206 & 60 & 0.08053 & 7.158 & 0.000 \\
Return on average asset & 0.01925 & 60 & 0.07461 & 1.473 & 0.146 \\
Return on average equity & 0.10553 & 60 & 0.78619 & 1.226 & 0.225 \\
Loan deposit ratio & 16.6738 & 60 & 75.9187 & 1.704 & 0.094 \\
\hline \hline Total & 46.78963 & 600 & 184.58465 & 50.193 & 0.58 \\
\hline
\end{tabular}

This table indicates the results of the ratio analysis through t-test and Anova. The profitability results of ROAA and ROAE are not significant as the $\mathrm{p}$ value is above than its criteria that is 0.05 . Liquidity results of current asset ratio, loan deposit ratio, net loan to total asset ratio and current ratio shows the significant results as the $p$ value is less than the 0.05. Capital adequacy is also showing significant results of equity liability ratio. Overall result of risk and solvency is significant that includes, debt equity ratio and debt to total asset ratio. Loan deposit ratio $\mathrm{p}$ value is above than its criteria means result is not significant.

\section{Findings}

Takaful insurance company profitability results are not significant. Our H1 hypothesis is that the Islamic insurance companies are more profitable than the conventional insurance companies. Now we reject the first hypothesis because the decision criterion $p$ value .05 of Islamic insurance companies does not showing the significance results. Our second hypothesis is that Islamic insurance company's liquidity is higher than the conventional insurance companies. Hence the results proved that the Islamic insurance company's liquidity is higher and results are also significant. So the second hypothesis H2 is accepted. H3 hypothesis is that Islamic insurance companies are less risky. The risk and solvency of Islamic insurance companies shows the significant results less than the 0.05 that's why the H3 hypothesis is accepted. H4 hypothesis is that Islamic insurance companies are well capitalized than the conventional insurance companies. The result significantly shows the equity liability ratio of Islamic insurance companies that's why H4 hypothesis is accepted. T-test result shows that the overall Islamic insurance companies performing well than the conventional insurance companies. Jointly value of t-test of Islamic insurance companies is 23.9and conventional insurance value is 50.193. There is a huge difference between the t-test values of Islamic and conventional insurance companies in Pakistan. The t-test value more close to the $\mathrm{p}$-value the better it is and Takaful insurance companies value is close to the $\mathrm{p}$ value than the conventional insurance companies.

\section{Conclusion}

In the light of the above study, results conclude that Islamic insurance companies perform well. The liquidity ratio, risk and solvency ratio and capital adequacy ratio gives the significant results of the $\mathrm{p}$ value and the profitability result is not significant.This study is going to help the investor, customer and institutions in making decision about the choice of insurance company.

The other aspect of this research paper is also discussed the difference between the Islamic and conventional insurance companies. Islamic insurance company saves themselves from the catastrophe by not using the Riba that is the main exploitive factor in the conventional insurance company's financial crises.

\section{Suggestions}

O Other test based on the E-views must be applied to measure the better performance of Islamic and conventional insurance companies.

O Since Islamic insurance companies are in the introductory phase in Pakistan. There is a strong need to conduct Performance evaluation studies from time to time so that corrective actions may be taken accordingly.

O This research provides new avenues for future research. Finding of this study generate a lot of questions in researchers mind; e.g. 
i. Why there is no difference between the profitability of both companies.

ii. Why Islamic insurance companies are more liquid than Conventional insurance.

iii. Why Islamic insurance are less risky than Conventional insurance companies.

iv. Why operational efficiency of Islamic insurance is better than Conventional insurance.

\section{Appendix:}

\begin{tabular}{|c|c|c|c|c|c|c|c|c|}
\hline S. No & Author/Year & Title & country & $\begin{array}{l}\text { Data/ } \\
\text { Sample }\end{array}$ & $\begin{array}{l}\text { Dependent } \\
\text { Variable }\end{array}$ & $\begin{array}{l}\text { Independent } \\
\text { Variables }\end{array}$ & Methodology & $\begin{array}{l}\text { Result/Significan } \\
\text { ce }\end{array}$ \\
\hline 1 & $\begin{array}{l}\text { Moghadam et al } \\
(2012)\end{array}$ & $\begin{array}{l}\text { performance } \\
\text { comparison of } \\
\text { insurance companies }\end{array}$ & Iran & $\begin{array}{l}\text { march to } \\
\text { dec, } 2011\end{array}$ & $\begin{array}{l}\text { performance } \\
\text { of the } \\
\text { company }\end{array}$ & $\begin{array}{l}\text { amount of the } \\
\text { premium } \\
\text { manufacturing and } \\
\text { ratio of } \\
\text { compensation }\end{array}$ & $\begin{array}{l}\text { descriptive } \\
\text { statistic ,Anova }\end{array}$ & $\begin{array}{l}\text { Iran needs to fast } \\
\text { growing in the } \\
\text { insurance sector. } \\
\text { Other countries } \\
\text { are } \\
\text { fast }\end{array}$ \\
\hline 2 & $\begin{array}{l}\text { Khan \&alam } \\
(2011)\end{array}$ & $\begin{array}{l}\text { comparative analysis of } \\
\text { Islamic and prevailing } \\
\text { insurance practices }\end{array}$ & Pakistan & $\begin{array}{l}2009 \text { to } \\
2011\end{array}$ & nill & nill & $\begin{array}{l}\text { Islamic ways, } \\
\text { Quran, Hadith } \\
\text { and Fatwas }\end{array}$ & $\begin{array}{l}\text { result in the favor } \\
\text { of Islamic } \\
\text { insurance } \\
\text { company }\end{array}$ \\
\hline 3 & $\begin{array}{l}\text { Muhammad } \\
\text { anwar }\end{array}$ & $\begin{array}{l}\text { comparative study of } \\
\text { insurance and } \\
\text { takaful(Islamic } \\
\text { insurance) }\end{array}$ & Malaysia & & nill & nill & $\begin{array}{l}\text { CIIP model and } \\
\text { Islamic } \\
\text { insurance }\end{array}$ & $\begin{array}{l}\text { result in the favor } \\
\text { of Islamic } \\
\text { insurance } \\
\text { company }\end{array}$ \\
\hline 4 & $\begin{array}{l}\text { Hussain \& pasha } \\
(2011)\end{array}$ & \begin{tabular}{|l|} 
conceptual and \\
operational differences \\
between general takaful \\
and conventional \\
insurance
\end{tabular} & Pakistan & $\begin{array}{l}1993 \text { to } \\
1996\end{array}$ & nill & nill & $\begin{array}{l}\text { Islamic and } \\
\text { conventional } \\
\text { comparison }\end{array}$ & $\begin{array}{l}\text { result in the favor } \\
\text { of Islamic } \\
\text { insurance } \\
\text { companies }\end{array}$ \\
\hline 5 & $\begin{array}{l}\text { Plantinga \& } \\
\text { Huijgen (2000) }\end{array}$ & $\begin{array}{l}\text { performance } \\
\text { measurement and } \\
\text { insurance liabilities }\end{array}$ & Groningen & 1997 & $\begin{array}{l}\text { performance } \\
\text { of the } \\
\text { company }\end{array}$ & $\begin{array}{l}\text { risk, ROA, surplus } \\
\text { return, PV of cash } \\
\text { flow }\end{array}$ & $\begin{array}{l}\text { liability driven } \\
\text { model Fischer- } \\
\text { Weil duration, } \\
\text { OLS }\end{array}$ & $\begin{array}{l}\text { Reduce agency } \\
\text { costs. }\end{array}$ \\
\hline 6 & Afzal \& Ahmed & $\begin{array}{l}\text { leverage choice and its } \\
\text { determinants: an } \\
\text { empirical investigation } \\
\text { of insurance sector in } \\
\text { Pakistan }\end{array}$ & Pakistan & $\begin{array}{l}2001 \text { to } \\
2007\end{array}$ & $\begin{array}{l}\text { leverage of } \\
\text { insurance } \\
\text { companies }\end{array}$ & $\begin{array}{l}\text { size, profitability, } \\
\text { tangibility of asset, } \\
\text { liquidity and risk }\end{array}$ & $\begin{array}{l}\text { descriptive and } \\
\text { regression } \\
\text { Analysis }\end{array}$ & $\begin{array}{l}\text { management is } \\
\text { profitable, } \\
\text { more liquid and } \\
\text { more tangible in } \\
\text { Pakistan }\end{array}$ \\
\hline 7 & Brogi (2003) & $\begin{array}{l}\text { regulation, corporate } \\
\text { governance and risk } \\
\text { management in banks } \\
\text { and insurance } \\
\text { companies }\end{array}$ & Italy & $\begin{array}{l}2001 \text { to } \\
2003\end{array}$ & $\begin{array}{l}\text { performance } \\
\text { of the } \\
\text { company }\end{array}$ & $\begin{array}{l}\text { Tobin's Q, ROA, } \\
\text { P/E }\end{array}$ & $\begin{array}{l}\text { one-tier, vertical } \\
\text { two-tier and } \\
\text { horizontal two } \\
\text { tier }\end{array}$ & $\begin{array}{l}\text { Two tier model is } \\
\text { newly introduces } \\
\text { in Italy. It is prove } \\
\text { to be effective in } \\
\text { financial } \\
\text { intermediaries } \\
\end{array}$ \\
\hline 8 & $\begin{array}{l}\text { Afzal \& Asghar } \\
(2010)\end{array}$ & $\begin{array}{l}\text { efficiency of insurance } \\
\text { industry in Pakistan: an } \\
\text { application of non- } \\
\text { parameter approach }\end{array}$ & Pakistan & $\begin{array}{l}2003 \text { to } \\
2007\end{array}$ & \begin{tabular}{|l} 
gross \\
premiums \\
and \\
investment \\
incomes
\end{tabular} & $\begin{array}{l}\text { labor, business } \\
\text { services, equity } \\
\text { capital and debt } \\
\text { capital }\end{array}$ & $\begin{array}{l}\text { Technical } \\
\text { Efficiency (TE), } \\
\text { Allocate } \\
\text { Efficiency (AE) } \\
\text { and Cost } \\
\text { Efficiency (CE) }\end{array}$ & $\begin{array}{l}\text { strong relationship } \\
\text { b/w insurance co. } \\
\text { in Pakistan }\end{array}$ \\
\hline 9 & $\begin{array}{l}\text { Swartz \& Coetzer } \\
(2010)\end{array}$ & $\begin{array}{l}\text { takaful: an Islamic } \\
\text { insurance instrument }\end{array}$ & $\begin{array}{l}\text { south } \\
\text { Africa }\end{array}$ & & nill & nill & \begin{tabular}{|l|} 
Islamic rules and \\
regulation are \\
followed
\end{tabular} & $\begin{array}{l}\text { weak relationship } \\
\text { b/w conventional } \\
\text { and takaful } \\
\text { insurance co. } \\
\end{array}$ \\
\hline 10 & $\begin{array}{l}\text { Mehdi } \\
\text { \&Sadegi(2010) }\end{array}$ & $\begin{array}{l}\text { the evolution of Islamic } \\
\text { insurance takaful } \\
\text { literature survey }\end{array}$ & Australia & & & & $\begin{array}{l}\text { difference of } \\
\text { Islamic and } \\
\text { conventional }\end{array}$ & $\begin{array}{l}\text { result in the favor } \\
\text { of Islamic } \\
\text { company } \\
\text { insurance } \\
\end{array}$ \\
\hline 11 & Noreen \& khan & $\begin{array}{l}\text { comparative efficiency } \\
\text { analysis of conventional } \\
\text { and takaful companies } \\
\text { in a Pakistan using data } \\
\text { envelopment analysis }\end{array}$ & Pakistan & 2006-2010 & $\begin{array}{l}\text { efficiency } \\
\text { and } \\
\text { productivity } \\
\text { of takaful } \\
\text { companies }\end{array}$ & $\begin{array}{l}\text { technical, allocate } \\
\text { and cost } \\
\text { efficiencies }\end{array}$ & $\begin{array}{l}\text { Data } \\
\text { Envelopment } \\
\text { Analysis }\end{array}$ & $\begin{array}{l}\text { not strong } \\
\text { relationship b/w } \\
\text { Islamic and } \\
\text { conventional } \\
\text { insurance } \\
\text { companies } \\
\end{array}$ \\
\hline 12 & $\begin{array}{l}\text { Sanaullah Ansari } \\
\text { \& Muhammad } \\
\text { Farooq }\end{array}$ & $\begin{array}{l}\text { THE DEMAND } \\
\text { DETERMINANTS OF } \\
\text { TAKAFUL (ISLAMIC } \\
\text { INSURANCE) BY } \\
\text { CONVENTIONAL } \\
\text { AND ISLAMIC } \\
\text { BANKS IN } \\
\end{array}$ & Pakistan & 2012 & \begin{tabular}{|l|} 
Takaful \\
Contribution \\
Ratio
\end{tabular} & $\begin{array}{l}\text { Leverage, Bank } \\
\text { Size, Long-Term } \\
\text { Debt Ratio and } \\
\text { Working Capital to } \\
\text { Total Assets Ratio, } \\
\text { Tax Consideration }\end{array}$ & $\begin{array}{l}\text { Descriptive } \\
\text { statistics, } \\
\text { Pearson } \\
\text { correlation and } \\
\text { common effect } \\
\text { model }\end{array}$ & $\begin{array}{l}\text { bank size, } \\
\text { working capital } \\
\text { results significant } \\
\text { but leverage, tax, } \\
\text { long term debts } \\
\text { are not significant }\end{array}$ \\
\hline
\end{tabular}


Comparative performance of Islamic and conventional insurance companies in Pakistan

\begin{tabular}{|c|c|c|c|c|c|c|c|c|}
\hline & & PAKISTAN & & & & & & \\
\hline 13 & $\begin{array}{l}\text { yon bahiah wan } \\
\text { aris }\end{array}$ & \begin{tabular}{|l|} 
THE DEMAND \\
DETERMINANTS OF \\
TAKAFUL (ISLAMIC \\
INSURANCE) BY \\
CONVENTIONAL and \\
ISLAMIC BANKS IN \\
PAKISTAN
\end{tabular} & Malaysia & $\begin{array}{l}1990 \text { to } \\
2003\end{array}$ & profitability & $\begin{array}{l}\text { employment, gdp, } \\
\text { inflation, zakat }\end{array}$ & $\begin{array}{l}\text { multiple } \\
\text { regression } \\
\text { analysis }\end{array}$ & \begin{tabular}{|l|} 
supports the \\
takaful companies \\
in ASEAN region
\end{tabular} \\
\hline 14 & $\begin{array}{l}\text { Norma Md. Saad } \\
(2012)\end{array}$ & \begin{tabular}{|l|} 
AN ANALYSIS ON \\
THE EFFICIENCY OF \\
TAKAFUL AND \\
INSURANCE \\
COMPANIES IN \\
MALAYSIA: A NON- \\
PARAMETRIC \\
APPROACH \\
\end{tabular} & Malaysia & $\begin{array}{l}2007 \text { to } \\
2009\end{array}$ & efficiency & \begin{tabular}{|l|} 
Premium, Net \\
Investment Income, \\
Commission, \\
Management \\
Expenses
\end{tabular} & $\begin{array}{l}\text { Data } \\
\text { Envelopment } \\
\text { Analysis }\end{array}$ & $\begin{array}{l}\text { the efficiency of } \\
\text { the takaful } \\
\text { companies is } \\
\text { found to be below } \\
\text { their conventional } \\
\text { counterparts. }\end{array}$ \\
\hline 15 & $\begin{array}{l}\text { Matsawali et all } \\
\text { (nov 2012) }\end{array}$ & $\begin{array}{l}\text { A Study on Takaful and } \\
\text { Conventional Insurance } \\
\text { Preferences: The Case } \\
\text { of Brunei }\end{array}$ & USA & & & & $\begin{array}{l}\text { survey, } \\
\text { questionnaire, }\end{array}$ & $\begin{array}{l}\text { Majority of public } \\
\text { prefer takaful than } \\
\text { the conventional } \\
\text { insurance. }\end{array}$ \\
\hline 16 & Muhammad Ayub & \begin{tabular}{|l|} 
An Introduction to \\
Takaful - An \\
Alternative to Insurance
\end{tabular} & & & & & Literature & \begin{tabular}{|l|} 
iterature gives \\
the results all \\
about Islamic \\
insurance \\
companies.
\end{tabular} \\
\hline 17 & $\begin{array}{l}\text { Asif Ahmed } \\
\text { Qureshi(2011) }\end{array}$ & $\begin{array}{l}\text { Analyzing the Shariah } \\
\text { compliant issues } \\
\text { currently faced by } \\
\text { Islamic Insurance }\end{array}$ & & & & & & $\begin{array}{l}\text { Shariah provides } \\
\text { its rules that are } \\
\text { all in the favors of } \\
\text { Islamic insurance } \\
\text { company. }\end{array}$ \\
\hline
\end{tabular}

\section{Acknowledgment}

First and foremost I would like to thanks my dear Allah, the most magnificent the most merciful who bestowed upon me the shower of abilities and skills.

Apart from the efforts of me, the success of any study depends largely on the encouragement and guidelines of many others. I would like to show my greatest appreciation to Prof. WaseemUllah and Prof.ZeeshanArshad. I can't say thanks to them enough for their tremendous support and help. Without their encouragement and guidance this study would not have materialized. On the last but not least special thanks to my mother whose prayers takes me towards my destination.

\section{References}

[1] Afza and Asghar (2012), financial reforms and efficiency in the insurance companies of Pakistan, African Journal of Business Management 6 (30), 8957-8963.

[2] Plantinga and Huijgen (1999), Performance measurement and insurance liabilities, University of Groningen.

[3] Hussain and Pasha (2011), CONCEPTUAL AND OPERATIONAL DIFFERENCES BETWEEN GENERAL TAKAFUL AND CONVENTIONAL INSURANCE, Australian Journal of Business and Management Research 1(8), 23-28.

[4] Khan et al (2011), Comparative Analysis of Islamic and Prevailing Insurance Practices, International Journal of Business and Social Science 2( 10)

[5] Muhammad Anwar (1994), comparative study of insurance and takaful (Islamic insurance), the Pakistan development review 33(4), 1315-1330.

[6] Matsawali et al (2012), A Study on Takaful and Conventional Insurance Preferences: The Case of Brunei, International Journal of Business and Social Science 3(22).

[7] Mehdi Sadeghi (2010), the evolution of Islamic insurance - Takaful: A literature survey, Insurance Markets and Companies: Analyses and Actuarial Computations 1(2).

[8] Moghadam et al (2012),PERFORMANCE COMPARISON OF INSURANCE COMPANIES, INTERDISCIPLINARY JOURNAL OF CONTEMPORARY RESEARCH IN BUSINESS 4(7).

[9] Noreen and Khan (), Comparative Efficiency Analysis of Conventional Insurance and Takaful Companies in Pakistan Using Data Envelopment Analysis.

[10] Norma Md. Saad, AN ANALYSIS ON THE EFFICIENCY OF TAKAFUL AND INSURANCE COMPANIES IN MALAYSIA: A NON-PARAMETRIC APPROACH Review Integrative Business Economic Research 1(1).

[11] Ansari and Farooq (2012), THE DEMAND DETERMINANTS OF TAKAFUL (ISLAMIC INSURANCE) BY CONVENTIONAL AND ISLAMIC BANKS IN PAKISTAN, 3rd INTERNATIONAL CONFERENCE ON BUSINESS AND ECONOMIC RESEARCH.

[12] Marina Brogi, REGULATION, CORPORATE GOVERNANCE AND RISK MANAGEMENT IN BANKS AND INSURANCE COMPANIES, Department of Banking, Insurance and Capital Markets.

[13] Swartz and Coetzer (2010), Takaful: An Islamic insurance instrument, Journal of Development and Agricultural Economics 2(10), 333-339.

[14] Afza and Ahmad, Debt Equity Choice of Life and Non-Life Insurers: Evidence from Pakistan, COMSATS Institute of Information Technology, Lahore, Pakistan.

[15] Yon Bahiah Wan Aris, Takaful-An Option to Conventional Insurance: A Malaysian Model. 
[16] Asif Ahmed Qureshi (2011), Analyzing the Shariah compliant issues currently faced by Islamic Insurance,INTERDISCIPLINARY JOURNAL OF CONTEMPORARY RESEARCH IN BUSINESS 3(5).

[17] Muhammad Ayub, An Introduction to Takaful - An Alternative to Insurance, Islamic Banking Department, State Bank of Pakistan Karachi.

[18] The universal insurance company limited financial reports, retrieved from may 20,2013, from http://uic.com.pk/index.php/financialhighlights/annual-reports/

[19] United insurance company limited of Pakistan financial reports retrieved from May 20 ${ }^{\text {th }}$, 2013, from http://www.theunitedinsurance.com/annual-reports.

[20] Shaheen insurance company limited financial reports retrieved from may 20,2013, from http://www.shaheeninsurance.com/

[21] Saudi pak insurance company limited financial reports retrieved from may 20,2013, from http://new.saudipakinsurance.com.pk/annual-reports

[22] Reliance insurance company limited financial reports retrieved from may 20, 2013 from

[23] PICIC insurance company limited financial reports retrieved from may 20, 2013 from http://www.picicinsurance.com/index.php/investor-information/financial-statements.html

[24] Premier insurance company limited financial reports retrieved from may 20, 2013 from http://www.pil.com.pk/financials.aspx

[25] Pakistan reinsurance company limited financial reports retrieved from may 20,2013 from http://www.pakre.org.pk/ms//index.php?option=com_content\&task=view\&id=82\&Itemid=191

[26] Pak Qatar family Takaful financial reports retrieved from may 20, 2013 from

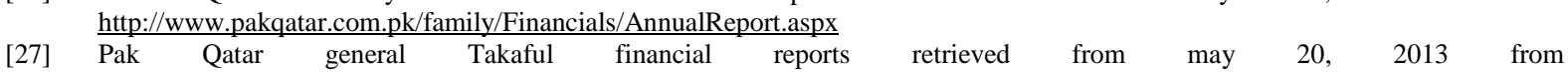

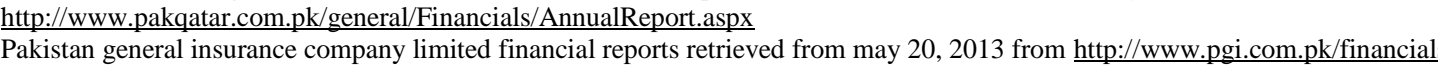

[28] Pakistan general insurance company limited financial reports retrieved from may 20, 2013 from http://www.pgi.com.pk/financials
[29] IGI insurance company limited financial reports retrieved from may 20,2013 from http://www.igiinsurance.com.pk/financial_Highlights_Yearly.asp

[30] Habib insurance company limited financial reports retrieved from may 20, 2013 from $\frac{\mathrm{http}: / / \mathrm{www} \text {.habibinsurance.net/financial highlights.htm }}{\mathrm{EFU} \text { general insurance company limited }}$ financial reports retrieved from may 20, 2013 from http://efuinsurance.com/FinancialReports.php

[32] Dawoodtakaful insurance company limited financial reports retrieved from may 20.2013 from http://www.dawoodtakaful.com/financial/

[33] Cyan limited insurance company limited financial reports retrieved from may 20, 2013 from

[34] Century insurance company limited financial reports retrieved from may 20, 2013 from http://www.cicl.com.pk/financialhighlights/annual-reports/

[35] Adamjee insurance company limited financial reports retrieved from may 20, 2013 from http://www.adamjeeinsurance.com/financials/financial reports.aspx

[36] Askari general insurance co ltd financial reports retrieved from may 20,2013 from http://www.agico.com.pk/reports.html

[37] Atlas insurance company ltd financial reports retrieved from may 20, 2013 from http://www.atlasinsurance.com.pk/financial statements

[38] Universal insurance company limited financial reports retrieved from may 20, 2013 from http://uic.com.pk/index.php/financialhighlights/annual-reports/ 